Acta vet. scand. 1987, 28, 263-269.

From the Department of Obstetrics and Gynaecology and the Department of Clinical Chemistry, Faculty of Veterinary Medicine, Swedish University of Agricultural Sciences, Uppsala, Sweden.

\title{
Clinical, Morphological and Endocrinological Studies in Gilts with Delayed Puberty
}

\author{
By A.-M. Dalin and L. Eliasson
}

\begin{abstract}
Dalin, A.-M. and L. Eliasson: Clinical, morphological and endocrinological studies in gilts with delayed puberty. Acta vet. scand. 1987, 28, 263-269. - Thirty-six gilts which had not shown oestrus at about 8 months of age or more were transported from the pig research station to the clinic, a journey of $12 \mathrm{~km}$. The gilts were examined by laparoscopy and those which had only small follicles in the ovaries were catheterized and placed in pens, with sexually mature boars kept in adjacent pens. Oestrus detection was done twice daily and blood was sampled three times a day. After 7 days the laparoscopy was repeated and gilts which still had only small follicles in their ovaries were given $250 \mu \mathrm{g} \mathrm{GnRH}$ intravenously the following day. Blood samples were taken frequently before and after $\mathrm{GnRH}$ treatment. One week after administration of GnRH the ovaries were inspected by laparoscopy once more.

The first laparoscopic examination showed that $42 \%$ of the gilts were sexually mature. One gilt had no uterus or ovaries. Twenty gilts had only small follicles in the ovaries and fourteen of these gilts showed ovulatory oestrus 5.5 days (4-7.5 days) after arrival. In these fourteen gilts a rise in the oestradiol-17B level ( $>30$ $\mathrm{pmol} / \mathrm{l}$ ) was seen at an average time of 1.9 days and a rise in LH (preovulatory peak) was seen at an averaged 4.5 days after the start of blood sampling. Six gilts were given $250 \mu \mathrm{g} \mathrm{GnRH}$. An immediate rise in LH could be seen in all the gilts (mean peak level was $6.18 \mu \mathrm{g} / \mathrm{l}$ ) and the elevated levels had a duration of 4 hours. None of the GnRH-treated gilts responded with oestrus symptoms or increased ovarian activity.
\end{abstract}

transport; oestradiol-17B; LH; GnRH-treatment.

\section{Introduction}

In Sweden gilts normally have their first oestrus at 6-7 months of age (Andersson et al. 1982). If no oestrus has been observed before 8 months of age, the gilts are considered to have delayed oestrus.

Factors known to stimulate the natural attainment of puberty in gilts are, for instance, boar contact, mixing, transportation and relocation.
Anoestrus is the most common reproductive disorder in gilts. Ehnvall et al. (1981) showed that among culled gilts older than 9 months, $34 \%$ of the culling cases were due to anoestrus.

Post-mortem examination of the genital organs of gilts slaughtered because of anoestrus revealed luteal tissue in the ovaries in approximately two thirds of the animals ( $E i$ narsson et al. 1974). The gilts had ovulated, 
but the external oestrus symptoms might have been weak or lacking. Inadequate oestrus detection is another possible explanation.

The aims of the present investigation were to study:

- the ovarian status in gilts which had not shown oestrus;

- the effect of transportation and relocation on the ovarian and endocrinal status in gilts with delayed puberty;

- the LH and ovarian response to GnRH in gilts with delayed puberty.

\section{Materials and methods}

The present investigation comprised 36 anoestrous gilts of Swedish Yorkshire breed from the pig research station at the Department of Animal Breeding and Genetics (Table 1). A total of 227 Swedish Yorkshire gilts were reared at the pig research station between 1983 and 1985 . The gilts were restrictedly fed. Oestrus detection was done twice daily from 160 days of age. Blood samples for progesterone determination were taken every 10 days from 170 days of age. From this age the gilts were also exposed to a boar. The boar was kept in an adjacent pen and once a day moved to the giltpens. Reproductive data from this herd are presented separately.
The gilts which had not shown oestrus at 8 months or more were taken to the Department of Obstetrics and Gynaecology, a journey of $12 \mathrm{~km}$. Within $20 \mathrm{~h}$ after arrival to the clinic, the gilts were examined by laparoscopy (Wildt et al. 1973). Gilts with corpora lutea or mature follicles (about 8-10 $\mathrm{mm}$ in diameter) were sent back to the research station, while the gilts with only small follicles in their ovaries were catheterized. The permanent catheter was placed in the jugular vein (Karlbom et al. 1982, Rodriques \& Kunavongkrit 1983). Both laparoscopy and catheterization were performed under general anaesthesia (pentol-sodium, $5 \%$ ). The gilts were placed in individual pens with sexually mature boars kept in adjacent pens. Oestrus detection was done twice daily and blood samples were taken three times daily ( 9 a. m., 12 noon and 3 p. m.). Laparoscopy was performed again on day 7. Gilts which still had only small follicles in their ovaries were given $250 \mu \mathrm{g}$ GnRH (LH-RH, NOVO Industry, A/S Copenhagen, Denmark) intravenously the following day. Blood samples were taken every $15 \mathrm{~min}$, starting $1 \mathrm{~h}$ before the injection and continuing for $3 \mathrm{~h}$ after. Blood samples were then taken every $30 \mathrm{~min}$ for $2 \mathrm{~h}$ and then every hour for $3 \mathrm{~h}$. During the following 6 days, blood was sampled 5 times a day (7

Table 1. Description of animals used in the study.

\begin{tabular}{llrlllll}
\hline Group & $\begin{array}{l}\text { Month of arrival } \\
\text { at the clinic }\end{array}$ & $\begin{array}{l}\text { No. of } \\
\text { gilts }\end{array}$ & $\begin{array}{l}\text { Mean age at } \\
\text { first laparo- } \\
\text { scopy (days) }\end{array}$ & $\begin{array}{l}\text { No. of gilts } \\
\text { sexually mature } \\
\text { at laparoscopy }\end{array}$ & $\begin{array}{l}\text { No. of gilts } \\
\text { in oestrus } \\
\text { within 8 days }\end{array}$ & $\begin{array}{l}\text { No. of gilts } \\
\text { GnRH-treated }\end{array}$ & $\begin{array}{l}\text { No. of gits } \\
\text { with mal- } \\
\text { formation }\end{array}$ \\
\hline A & November 1983 & 11 & 243.3 & 9 & 1 & - & 1 \\
B & April 1984 & 7 & 252.6 & 3 & 2 & 2 & \\
C & September 1984 & 9 & 283.6 & 1 & 6 & 2 & \\
D & December 1984 & 3 & 245.0 & 2 & 1 & - & \\
E & May 1985 & 6 & 255.2 & 0 & 4 & 2 & 1 \\
\hline Total & 36 & 257.3 & 15 & 14 & 6 & \\
\hline
\end{tabular}


a. m. until 7 p. m.) and oestrous detection was done twice daily.

One week after the GnRH treatment the ovaries were inspected by laparoscopy.

All blood samples were collected in heparinized tubes, centrifuged as soon as possible and after sampling the plasma was then stored at $-18^{\circ} \mathrm{C}$ until assay.

\section{Hormone assay}

Blood plasma levels of $\mathrm{LH}$ were determined by radioimmunoassay. The assay system utilized an antiserum to ovine LH (Niswender et al. 1969). Porcine LH (LER-786-3) was used for radioiodination by the chloramine-T method and as standard. The use of these reagents for radioimmunoassay of porcine LH has previously been described (Niswender et al. 1970). Separation of free and antibody-bound hormone was done with a second antibody to rabbit gammaglobulin coupled to a solid phase (DASP, Organon, The Netherlands). The analyses of pooled plasma in 19 assays resulted in a mean value of $1.05 \mu \mathrm{g} / 1$ (SD = $0.29 \mu \mathrm{g} / \mathrm{l})$. All values presented represent the mean of duplicate determinations. Progesterone and oestradiol-17B were determined by radioimmunoassay (Edqvist \& Johansson 1972) using antisera to a 11-a-hydroxyprogesterone (Bosu et al. 1976) and 6-ketooestradiol-17B (Boilert et al. 1973). The analyses of pooled plasma in 22 assays resulted in a mean value of $1.14 \mathrm{nmol} / 1(\mathrm{SD}=0.36$ $\mathrm{nmol} / \mathrm{l})$ and $29 \mathrm{pmol} / \mathrm{l}(\mathrm{SD}=5.4 \mathrm{pmol} / \mathrm{l})$ for progesterone and oestradiol-17B, respectively. All oestradiol-17B values represent the mean of duplicate determinations. Based on the analyses of plasma samples from an ovariectomized sow, we have previously defined the practical detection limit of this assay to be $24 \mathrm{pmol} / \mathrm{l}$ (Andersson et al. 1983a).

\section{Results}

The number of animals in the different groups, the date of arrival at the clinic and the mean age at first laparoscopy are presented in Table 1 . The mean age of the 36 gilts at first laparoscopy was 257.3 days (233-289 days). The first laparoscopic examination showed 15 gilts to be sexually mature. These gilts had a mean age of 250.9 days (233-286 days). Twelve of these gilts had corpora lutea in the ovaries, the mean number of corpora lutea being $10.3(8-13)$. Three gilts had mature follicles in the ovaries (diameter about $10 \mathrm{~mm}$ ) and these gilts were in oestrus. One of the gilts lacked both ovaries and uterus, as was detected by laparoscopy. This observation of a malformation was confirmed at post-mortem examination. The vagina was small and blind at the cranial part.

Twenty gilts had only small follicles in the ovaries ( $<6 \mathrm{~mm}$ in diameter). Fourteen of the gilts showed oestrus 5.5 days (4-7.5 days) after arrival, at a mean age of 271.0 days (244-295 days). Eleven of these gilts had a normal standing reflex and 2 had a weak standing reflex, while 1 did not stand for a boar despite reddening and swelling of the vulva.

In the 14 gilts showing oestrus within 8 days a rise in the oestradiol-17ß level $(>30$ pmol/l) was observed at an average time of 1.9 days (0-5 days) and a rise in LH (prevulatory peak) was seen at an average of 4.5 days (3-7 days) after the start of blood sampling. The mean progesterone level was low $(<0.6 \mathrm{nmol} / \mathrm{l})$ before the first oestrus. The average duration of elevated oestradiol-17B levels and LH levels was 4 and 1.5 days, respectively (Fig. 1).

The second laparoscopic examination performed 7 days after the first one confirmed the clinical observation of oestrus, either by newly formed corpora lutea or by mature 

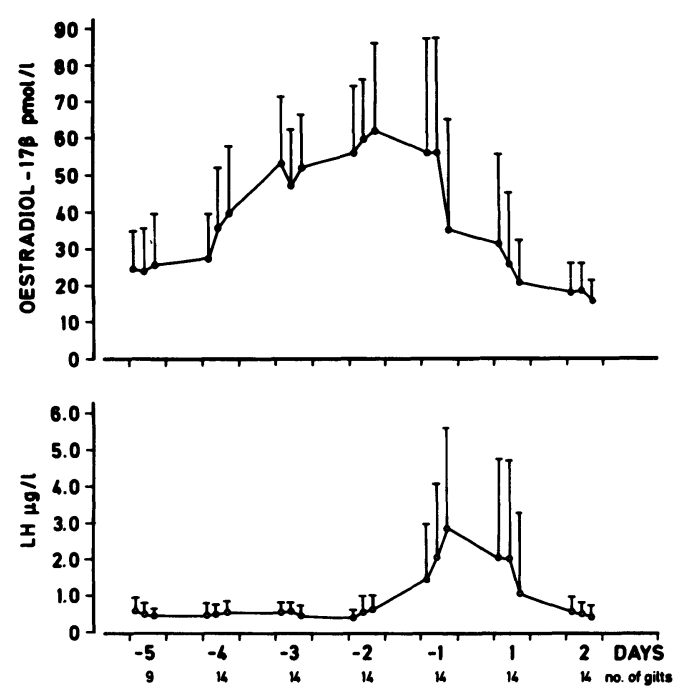

Figure 1. Plasma levels (mean $\pm \mathrm{SD}$ ) of oestradiol-17B and LH in 14 gilts showing oestrus after arrival at the clinic. Day 1 is the first day of oestrus (standing reflex).

follicles. No change in follicular size could be observed at the second laparoscopy in six of the animals. In these gilts, $250 \mu \mathrm{g} \mathrm{GnRH}$ was injected on day 8 after the first laparoscopy. One gilt had to be slaughtered due to leg weakness 4 days after the GnRH inject- ion. Post-mortem examination revealed only small ovarian follicles $(\leq 6 \mathrm{~mm}$ in diameter). The other 5 gilts were examined by laparoscopy 7 days after GnRH treatment and no difference in follicular size could be discovered in these animals. No clinical signs of oestrus were observed in any of the gilts after the GnRH treatment. An immediate sharp rise of LH after the GnRH injection could be seen in all the gilts. The mean level of LH just before treatment was $0.50 \pm 0.44 \mu \mathrm{g} / \mathrm{l}$ and the mean peak level was $6.18 \pm 2.56 \mu \mathrm{g} / \mathrm{l}$, observed in all animals 60 minutes after the GnRH injection. The elevated LH levels lasted for $4 \mathrm{~h}$ (Fig. 2). The mean oestradiol-17B-level $(<24$ pmol/l, Fig. 2) as well as the mean progesterone level $(<0.60 \mathrm{nmol} / \mathrm{l})$ per day were low in all animals during the whole blood sampling period.

\section{Discussion}

The mean ages of the gilts in the 5 different groups (A, B, C, D and E) at arrival at the clinic and at the first laparoscopic examination were 243.3, 252.6, 283.6, 245.0 and 255.2 days respectively. The gilts arriving in September (group C) were the oldest, but only 1 of the 9 gilts was sexually mature at

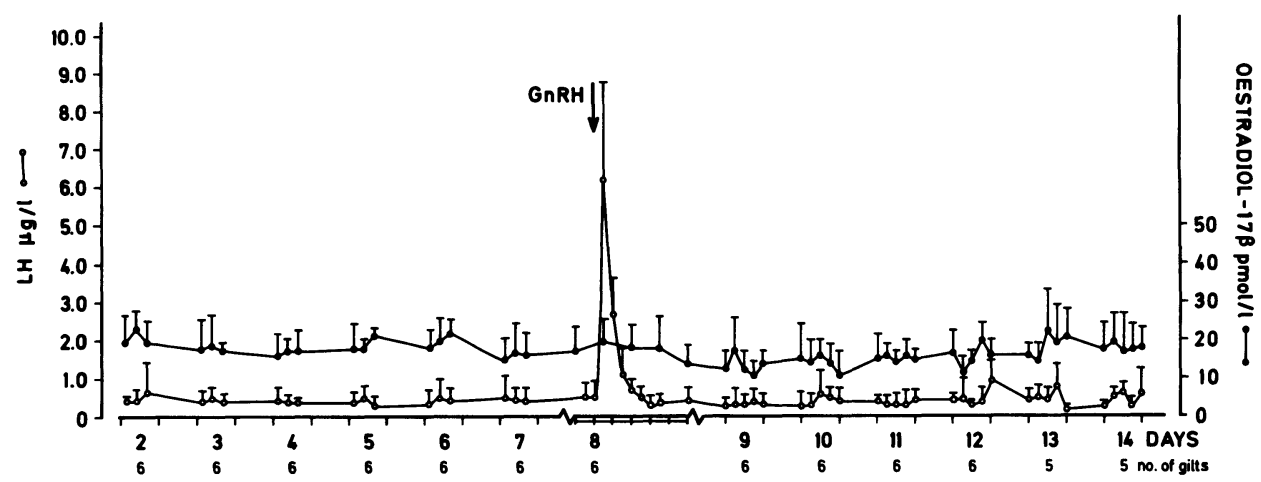

Figure 2. Plasma levels (mean $\pm \mathrm{SD}$ ) of oestradiol-17B and LH before and after treatment with $250 \mu \mathrm{g}$ GnRH in 6 gilts with delayed puberty. 
arrival. For this reason, a seasonal effect causing the delayed puberty in this group can not be excluded (cf. Ehnvall et al. 1981). Twelve gilts (33.3\%) had passed their first oestrus at the research station without this being recorded. The ovulations were confirmed by the laparoscopic examination of the ovaries. The external oestrus symptoms must have been weak in these gilts. Three gilts $(8.3 \%)$ had large follicles in the ovaries at arrival at the clinic and showed standing reflex when tested with a boar. The external signs of oestrus in the form of reddening and swelling of the vulva were however weak.

The uterus and ovaries were found to be missing in 1 of the gilts. No such malformation had been found in an earlier study of the genital organs from 1000 gilts (Einarsson \& Gustafsson 1970).

Twenty of the gilts $(55.6 \%)$ were not sexually mature at the arrival at the clinic. Fourteen of these gilts $(70 \%)$ showed oestrus within 7.5 days. The effect of transportation and/or a change in the environment on ovarian activity has been reported earlier by e.g. Paredis (1961) and du Mesnil du Boisson \& Signoret (1962). Paredis (1961) showed that $62 \%$ of gilts aged 7-12 months showed oestrus within 7 days after transportation and a change in the environment. The gilts showing ovulatory oestrus had ovarian follicles $\leq 5 \mathrm{~mm}$ in diameter at arrival at the new place. Du Mesnil du Boisson \& Signoret $(1962)$ on the other hand suggested that gilts must have follicles measuring $5-8 \mathrm{~mm}$ in diameter to be stimulated to oestrus by transportation. In the present study no marked difference in the ovaries between gilts showing and gilts not showing oestrus within one week was seen at the arrival at the clinic.

Elevated levels of oestradiol-17B ( $>30$ $\mathrm{pmol} / \mathrm{l}$ ) were found soon after arrival at the new place in those gilts which showed oestrus during the first week. The effect of transportation/change in environment on ovarian activity must have been almost immediate. The duration of elevated oestradiol-17B levels was approximately the same as in gilts showing their first oestrus at normal age (Andersson et al. 1983a).

Six gilts were given $250 \mu \mathrm{g} \mathrm{GnRH}$ intravenously and a rise in $\mathrm{LH}$ was observed immediately after the GnRH injection in all the gilts. This indicates that gilts with delayed puberty do not have an LH deficiency in their hypophyses. Five of the gilts did not exhibit oestrus within one week and the sixth, which was slaughtered 4 days after injection due to leg weakness, had immature follicles ( $\leq 6 \mathrm{~mm}$ in diameter) in the ovaries. Identical results were obtained in an earlier study (Andersson et al. 1983b) when prebuberal gilts (at 141 and 173 days of age) were treated with one single $250 \mu \mathrm{g}$ injection of GnRH. Carpenter \& Anderson (1985) studied the effects of pulsatile infusion of LHRH in prepuberal gilts during a 12-day period. Only 1 gilt (age 151 days) out of 4 ovulated but this gilt did not return to oestrus. Lutz et al. (1985) reported that hourly intravenous administration of $\mathrm{GnRH}$ $(1 \mu \mathrm{g})$ for 7-8 days in prepuberal gilts (age 164 days) induced oestrus within 6 days. However, only 1 of the 3 gilts returned to oestrus and ovulated 3 weeks later. The results of these studies indicate that final sexual maturation occurs at the hypothalmic level. Edqvist et al. (1978) reported that 3 out of 4 gilts (mean age 10.8 months) with delayed puberty showed ovulatory oestrus within 7 days after one $1000 \mu \mathrm{g}$ injection of GnRH. None of these gilts had been exposed to transportation/change in environment before the GnRH treatment. The stress experienced by the gilts (restrained) in connection with frequent blood sampling from an ear vein may have induced the sexual maturity. 


\section{Conclusions}

The present results indicate that

- what has previously been interpreted as anoestrus may in fact be weak or missing external oestrus symptoms;

- transportation/change in environment may induce ovulatory oestrus in gilts with delayed puberty;

- gilts not coming into oestrus after environmental stimulation respond to GnRH treatment with a LH surge without subsequent oestrus.

\section{Acknowledgements}

This investigation was supported by grants from the Swedish Council for Forestry and Agricultural Research. The Department of Animal Breeding and Genetics is gratefully acknowledged for supplying the gilts. Thanks are also due to Prof. Stig Einarsson for valuable advice and to Marianne Carlsson, Eva Hedberg, Mari Wallbring and Carina Ahlstedt for their excellent technical assistance.

Antiserum to ovine LH was kindly donated by Dr. G. D. Niswender, Colorado State University, Fort Collins, USA. The authors are indebted to Dr. L. E. Reichert for supplying porcine LH for iodination and as standard.

\section{References}

Andersson A-M, Einarsson S, Karlbom I: A study of the occurrence of silent and/or anovulatory heats in peripubertal gilts. International Pig Veterinary Society Congress, Mexico. Proceedings, 1982, p. 236.

Andersson $A-M$, Einarsson $S$, Edqvist L-E: Prepubertal LH, oestradiol-17B and progesterone pattern in gilts, Zbl. Vet. Med. A. 1983a, 30, 438-446.

Andersson $A-M$, Einarsson $S$, Edqvist L-E: Treatment with gonadotropin releasing hormone in prepubertal gilts at two different ages. Acta vet. scand. 1983b, 24, 446-455.

Boilert B, Edqvist L-E, Johansson EDB, Lindberg $P$, Martinsson $K$ : The influence of conjugated estrogens in radioimmunoassays using different antibodies against estradiol-17B. Steroids 1973, 22, 891-894.

Bosu WTK, Edqvist L-E, Lindberg P, Martinsson $K$, Johansson EDB: The effect of various dosages of lynestrenol on plasma levels of oestrogen and progesterone during the menstrual cycle in rhesus monkey. Contraception 1976, 13, 677-684.

Carpenter LS, Anderson LL: Pulsatile infusion of luteinizing hormone-releasing hormone: Effects on luteinizing hormone secretion and ovarian function in prepubertal gilts. Anim. Repr. Sci. 1985, 9, 261-272.

Du Mesnil Du Boisson F, Signoret JP: Influences de facteurs externes sur le déclechement de la puberté chez la truie. (Influence of external factors on the onset of puberty in the gilt). Ann. Zootech. 1962, 11, 53-59.

Edqvist L-E, Johansson EDB: Radioimmunoassay of oestrone and oestradiol in human and bovine peripheral plasma. Acta Endocrinol. (Kbh.) 1972, 71, 716-730.

Edqvist L-E, Einarsson S, Karlbom I, Viring S: The hormonal and clinical response of gilts with delayed puberty to GnRH. A preliminary study. Theriogenology 1978, 9, 401-407.

Einarsson S, Linde C, Settergren I: Studies of the genital organs of gilts culled for anoestrus. Theriogenology 1974, 2, 109-113.

Einarsson S, Gustafsson B: Developmental abnormalities of female sexual organs in swine. A post-mortem examination of the genital tract in 1000 gilts. Acta vet. scand. 1970, 11, 427-442.

Ehnvall $R$, Blomqvist A, Einarsson $S$, Karlberg $K$ : Culling of gilts with special reference to reproductive failure. Nord. Vet.-Med. 1981, 33, 167-171.

Karlbom I, Einarsson S, Edqvist L-E: Attainment of puberty in female pigs. Clinical appearance and patterns of progesterone, oestradiol17B and LH. Anim. reprod. Sci. 1982, 4, 301 -312 .

Lutz JB, Rampacek GB, Kraeling RR: Induction of ovulation in the prepuberal gilt by pulsatile administration of gonadotropin-releasing hormone. Domest. Anim. Endocrinol. 1985, 2, 61-65. 
Niswender GD, Reichert L-E Jr, Midgley $A R J r$, Nalbandov $A V$ : Radioimmunoassay for bovine and ovine luteinizing hormone. Endocrinology 1969, 84, 1166-1173.

Niswender GD, Reichert L-E Jr, Zimmermann $D R$ : Radioimmunoassay of serum levels of luteinizing hormone throughout the estrus cycle in pigs. Endocrinology 1970, 87, 576-580.

Paredis F: Onderzoekingen over vruchtbaarheid en kunstmatige inseminatie bij het varken. (Studies on reproduction and artificial insemination in pigs). PhD Thesis, Gent 1961.

Rodriguez $H$, Kunavongkrit A: Chronical venous catheterization for frequent blood sampling in unrestrained pigs. Acta vet. scand. 1983, 24, 318-320.

Wildt DE, Fujimoto S, Spencer JL, Dukelow $W R$ : Direct ovarian observation in pigs by means of laparoscopy. J. Reprod. Fert. 1973, $35,541-543$.

\section{Sammanfattning}

Kliniska, morfologiska och hormonella studier av gyltor med försenad könsmognad.

Trettiosex gyltor som inte hade visat brunst vid ca 8 månaders ålder transporterades $12 \mathrm{~km}$ från en försöksstation till kliniken. Gyltorna undersöktes med laparoskopi. På gyltor som bara hade små folliklar $i$ äggstockarne opererades en kateter in för blodprovstagning och därefter placerades gyltorna i boxar med könsmogna galtar i närheten. Brunstkontroll utfördes 2 gånger och blodprov togs 3 gånger per dag. Efter 7 dagar upprepades laparoskopi-undersökningen och gyltor som fortfarande bara hade små folliklar i äggstockarna behandlades med $250 \mu \mathrm{g}$ GnRH i.v. följande dag. Frekvent blodprovstagning utfördes $\mathrm{i}$ anslutning till GnRH-behandlingen och 5 ggr per dag därefter. En vecka efter GnRH-behandlingen undersöktes gyltorna på nytt med laparoskopi. Den första laparoskopi-undersökningen visade att $42 \%$ av gyltorna var könsmogna. En gylta saknade livmoder och äggstockar. Tjugo gyltor hade små folliklar i äggstockarna och av dessa visade 14 brunst 5,5 dagar (4-7,5 dagar) efter ankomsten till kliniken. Hos dessa 14 gyltor sågs en östradiol-17B stegring ( $>30 \mathrm{pmol} / \mathrm{l}$ ) efter i medeltal 1.9 dagar och en stegring av LH (preovulatorisk stegring) efter i medeltal 4.5 dagar från blodprovstagningens början. Hos de 6 gyltorna som behandlades med GnRH sågs omedelbart en LH-stegring. Medelvärdet för maximumnivåen var $6.18 \mu \mathrm{g} / 1$ och LH-stegringen hade en duration på 4 timmar. Ingen av gyltorna svarade med brunst eller ökad äggstocksaktivitet efter GnRH-behandlingen.

(Received February 2, 1987).

Reprints may be requested from: A.-M. Dalin, Department of Obstetrics and Gynaecology, P. O. Box 7039, Swedish University of Agricultural Sciences, S-750 07 Uppsala, Sweden. 
